\title{
Juridical Analysis on the Procurement of Goods/ Services of the Government to Realize Good Governance (Research Studies in the Department of Human Settlements and Layout Batam City)
}

\author{
Hamidi $^{1}$, Sabela Gayo ${ }^{2}$, Ariman Sitompul ${ }^{3}$ \\ ${ }^{1}$ Advokat in Batam, Riau Kepulauan Province, Indonesia \\ ${ }^{2}$ Lecturer Program Master of Law Universitas Bhayangkara Jakarta Raya, Indonesia \\ ${ }^{3}$ Lecturer Program Master of Law Universitas Dharmawangsa-Medan, Indonesia \\ Corresponding Author: Hamidi [Email: hamidi0608@yahoo.com]
}

\begin{abstract}
The objectives of this research are to know how setup law on public procurement on goods/ services, how the implementation of public procurement $o$ and what are the barriers factors and alternative solutions in public procurement. The writing methods are normative and empirical methods. The result of this study has shown that Presidential Decree Number 16 Years 2018 as the legal arrangements for public procurement can be used as complete guidelines in the public procurement on goods/services; the implementation of the legal arrangements are not optimal yet; there is an overlap of job function and human resources competencies is not complied yet. The recommendation of this study are the implementation of Presidential Decree Number 16 Years 2018 will be effective since there is local regulations/Mayor Decree as a technical guidance to things that are still not regulated, so that the legal arrangements for the public procurement on goods/services can be used as complete guidelines in the public procurement; must develop the level of compliance in implementing or implementing the Presidential Decree and several other technical regulations; make a clear of job description and human resources competencies need to be improved.
\end{abstract}

Keywords: Legal Arrangements, Implementation, Barrier Factors

\section{INTRODUCTION}

The system of procurement of goods/services that better is the system of procurement of goods/services that are able to apply the principles of good governance (good governance) to encourage efficiency and effectiveness of public spending, as well as the arrangement of the behavior of the three pillars (government, private and public) in the implementation of good governance, as the government has issued a policy in the settings of the procurement of government goods/services stipulated in Presidential Regulation Number 16 Year 2018 on Procurement of Goods/Services of the Government. On the implementation of the procurement of goods/services of the government to realize Good Governance, regarding the financial governance of the country is often found problems in the procurement of goods/services of the government are in the realm of Administrative Law, Civil Law, or Criminal Law.

Repair system for the procurement of goods/services not only from the side of a rule or regulation of the course of the implementation of the procurement of goods/services of the government of Indonesia also continues to increase the capacity of the human resources (HR) and the implementation of e-procurement. Human resource development is done by making the standardization of the 
competence of personnel procurement through the professional certification program for the Procurement of Goods/services of the Government and the determination of the Functional Manager for the Procurement of Goods/services of the Government. The construction of the electronic system, e-procurement, starting in 2003 through Presidential Decree No. 80 of 2003 on Guidelines for the Procurement of Goods/services of the Government, any agency start allowed the use of information technology in procurement.

The contract for the procurement of goods/services is a contract made on the activities of government goods/services procurement. Procurement of government goods/services hereinafter referred to as Goods/Services Procurement is the procurement of goods/services by the Ministry/Institution/Regional financed by the Budget of Revenue and Expenditure of the State /Regional Revenue and Expenditure Budget process since the identification of needs, up to the handover of the results of the work. Some of the problems in the contract for the procurement of goods/services of the government which is always the case is in connection with the extension of the time of execution of the work, termination of the contract unilaterally, the provider of goods/services that is entered into the black list, the price adjustment in the implementation of the contract, the payment of the achievements of the work, the circumstances of force majeure, the goods are discontinued, the presence of subcontracting and the problem of delay penalty.

Some of the cases that occur in the procurement of goods/services, caused by the absence of a good understanding and less rigorous on the official procurement of goods/services from the planning, implementation, even up to the handover of the results of the work. Other problems in the implementation of procurement of goods/services are; there are still many officials such as Commitment Officer, the working Group Elections/PP/PPTK do not realize that the consequences settings tender or direct appointment erroneous, can cause unlawful acts;many Commitment Officer who do not read and understand well against the tender documents or the contract will be signed. Whereas the tender documents is the legal basis for the providers of goods/services and the user of the goods/services in the tender (the Book of the Law of Civil Law Article 1338). Some Commitment Officer does not understand the meaning and provisions outlined in the tender document/contract document, so that the result is a lot of give rise to a claimclaims that can not be avoided, which then had to be met in the implementation of the contract. Presidential regulation Number 16 Year 2018 determined that for complex contract or worth over Usd.100.000.000.000 (one hundred billion rupiah), before signature of the contract, then it must have the approval of the Expert Contract Law / Contract Construction. Law Enforcement officers and Auditors who have the knowledge and understanding of a very limited system of procurement of goods/services of the government and its authority in solving the problems of procurement of goods/services, so often make mistakes in understanding and set the status of the case, including a civil case or a criminal.

\section{LITERATURE REVIEW}

According to Austin, the elements of law in Austin include the presence of the ruler (Sovereignty), a command (command), the obligation to obey the (duty), the sanctions for those who do not obey (sanction). Austin considers the law as a system that is logical, fixed and are closed. According to him, the law actually contains four elements: the command, sanction, duty, and authority. Short legal according to John Austin:

1. The Law is the command of the ruler (the law is a command of the lawgiver), the law is seen as the order of the holder of supreme power. 
2. Law is a system of logic which is fixed and closed.

3. Positive Law must meet some of the elements of the command, sanction, duty, and authority, on the outside it is not the law but the moral positive.

The theory of Legal Development (development of theory of law), a theory that is raised from the study of the law according to the perspective of political science. Nonet \& Selznick introduced the three types of law in the theory of the construction of the law, namely: the Type of Repressive Law; the Theory of Autonomous Law, and Legal Theory Responsive. In general, Philippe Nonet and Philip Selznick distinguish three basic classification of law in society, which is composed of:

1. The Law as a waitress power of repressive.

2. The Law as an institution of its own that is able to tame the repression and protect the integrity of himself, and

3. The Law as a facilitator of a variety of response to the needs \& aspirations of social

According To Lawrence $\mathrm{M}$. Friedman, the legal system is built by three components, namely: the structure of the law (legal structure), the substance of the law (legal substain), and legal culture (legal culture).

a) The Structure of the Law (Legal Structure)

Mean is a framework or skeleton, parts of which still survive, the one that gives a sort of shapes and restrictions on the whole.

b) The Substance of the Law (Legal Substain)

The substance of the law determines whether or not a law can be implemented. In addition, the substance of the law include the law of life (living law), not just the rules that are in the book of the law (law books). And the law of life in the community can be used as a reference in building equitable law.

c) Legal Culture (Legal Culture)
Legal culture is the human attitude towards the law and legal system of beliefs, values, thoughts and wishes. Legal culture is the social mind and social forces that determine how the law is used, avoided, or misused.

In upholding the rule of law, the third component, the legal system should be developed simultaneously and integral. Mochtar Kusumaatmadja in theory construction law states that the law as a tool updates and community development, which serves to maintain order in a society that is being built. Development is also aligned with the word of social change. The basic construction of the law of sustainable can be seen from the foundation of philosophical and constitutional contained in the fourth paragraph.

\section{MATERIAL AND METHODS}

Specification of this research is a normative legal research or doctrinaire which is also called as library research (library research). To support the analysis of the juridical such, this study also uses dataprimary data (Empirical Methods).Data collection techniques namely with the literature study, observation and interview. The technique of data analysis done with the "IRAC" that is to choose the issue (issues), specify the relevant legal regulations (ruleoflaw), and then analyze the facts in terms of the law (analysingthefacts), ultimately resulting in the preparation of a conclusion (the conslusion).

\section{RESULTS AND DISCUSSION \\ The Settings of the Law on the Procurement of Goods/Services of the Government}

As for the legal field associated with the procurement of goods/services of the government is:

\section{The Field of Administrative Law, State Law, State Administrative}

The rules of administrative law in Indonesia is Law Number 30 of 2014 On Government Administration. The state administration is a procedure in decision- 
making and/or action by the agency and/or government officials. In this process the user the goods/services of government agencies (Budget Users/Power Users of the Budget act as officials of the country/region is not represented country/area as an individual/personal. All decisions issued in this process is the decision of officials of the state or territory or the public. Government officials have the right to use the authority to make decisions and/or actions. In terms of the Law of the State administration, the decision of the competent authority that is considered contrary to the provisions of applicable law or contrary to the General Principles of good Governance, the party who feels aggrieved can file a lawsuit the administration of the country to the administrative court.

\section{The Field of Civil Law}

The legal relationship between the user with a provider that occur in the process of signing the contract for the procurement of goods/services to process the expiration of the contract is the relationship of civil law in particular the contractual relationship/agreement. The contract for the procurement of goods/services namely in the form of a written agreement between the KDP with your provider or implementing selfmanaged.

\section{The Field of Criminal Law}

Criminal law will protect the rights and interests of users and providers of goods. Deviations that occur in the process of procurement of goods/services for the benefit of the government can be qualified as something that is "against the law" (wederechtelijk).

In the 1945 Constitution of the Republic of Indonesia, Article 33 paragraph (4) of the 1945 Constitution of the Republic of Indonesia states that the national economy is organized on economic democracy with the principles of togetherness, efficiency, justice, sustainability, environmental insight, independence, and by maintaining balance of progress and national unity. It is clear that Article 33 contains the idea of economic democracy which has a characteristic that the process of its realization by all members of the community is for the benefit of the whole community, and must serve the welfare of the people.

Improvements in the procurement system for goods and services are not only in terms of rules or regulations, in terms of the implementation of the procurement of goods and services, the Indonesian government also continues to increase the capacity of human resources (HR) and the implementation of e-procurement. Human resource development is carried out by standardizing the competence of procurement personnel through a professional certification program for the Government Procurement of Goods and Services and the establishment of the Functional Position for Procurement Manager of Government Goods and Services. The development of an electronic system, namely e-procurement, began in 2003 through Presidential Decree Number 80 of 2003 concerning Guidelines for the Procurement of Government Goods and Services, every agency was allowed to use information technology in procurement. Electronic procurement (e-procurement) aims to; (1) Increasing transparency and accountability, (2) Increasing market access and fair business competition, (3) Meeting the need for access to real time information.

Procurement of goods/services based on Article (3) of Presidential Regulation Number 16 of 2018, includes: goods, construction work, consulting services and other services. In article (1) number 1 of Presidential Regulation Number 16 of 2018, the definition of Government Procurement of Goods/Services is the activity of Procurement of Goods/Services by Ministries/Institutions/Regional

Apparatuses financed by the State Revenue and Expenditure Budget/Revenue and Expenditure Budget Region whose process starts from the identification of needs, until the handover of the work. 
The procurement of goods/services as referred to in Article 2 paragraph (1) of Presidential Regulation Number 16 of 2018 can be carried out in an integrated manner. The procurement of goods/services as referred to in paragraph (1) is carried out by means of Self-Management and/or Providers.

The procurement policy in the procurement of goods/services based on the Article (5) Presidential Regulation Number 16 Year of 2018, covering;

a. Improve the quality of planning for the Procurement of Goods/Services;

b. Carry out the Procurement of Goods/Services that is transparent, open and competitive;

c. Strengthen the institutional capacity and human resources for the Procurement of Goods/Services;

d. Developing an E-marketplace for the Procurement of Goods/Services;

e. Use of information and communication technology, as well as the electronic transactions;

f. Encourage the use of the goods/services in the country and the Indonesian National Standard;

g. Provide an opportunity to Micro, Small, and Medium-sized Businesses;

h. Implementing Sustainable Procurement.

Principles of Procurement of Goods/Services of the Government as contained in Article (6) Presidential Regulation Number 16 Year 2018, is the:

\section{a. Efficient}

Efficient means for the Procurement of Goods/Services must be cultivated with the use of the funds and the minimum power to achieve the quality and objectives within a set time to achieve results and targets with maximum quality.

b. Effective

Effective means for the procurement of goods/services shall be in accordance with the needs and sasaranyang set and give the maximum benefit.

\section{c. Tansparan}

Transparent means all the provisions and information on the procurement of goods/services are clear and widely known by the provider of the goods/services that are interested as well as by the community at large.

d. Open

Open means the procurement of goods/services can be followed by all providers of goods/services that meet the requirements/criteria based on clear rules and procedures.

e. Fair

Fair means giving equal treatment to all candidates who are interested to realize the presence of healthy competition and did not lead to give the benefit of the parties trtentu and/or any reason.

\section{f. Accountable}

Accountable means to be in accordance with the rules and regulations related to procurement of goods/services so that it can be accounted for.

The Implementation of the Procurement of Government Goods/Services at the Batam City Spatial Planning and Creation Service

The implementation of the procurement of goods/services in the Batam City Government based on the Regulations of the Mayor of Batam Number 54 Year 2019 About the Organizational Structure and Working procedures of the Regional Secretariat and the Secretariat of the parliament, the Regulation of the Mayor of Batam No. 56 of 2019 About the main Tasks, Functions and Duties of the Regional Secretariat and the Secretariat of the parliament, the Regulation of the Mayor of Batam Number 49 Years 2019 On Guidelines for the Procurement of Direct Electronically, the Decision of the Mayor of Batam Number: KPTS.319/HK/XII/2018 About the Standard Operating Procedures of the Procurement of Goods and Services Batam City Regional Secretariat. The activities of procurement of goods/services financed in whole or in part from funds of 
the State Budget or the Regional Revenue and Expenditure Budget.

The regulations of the Mayor of Batam No. 56 of 2019 About the main Tasks, Functions and Duties of the Regional Secretariat and the Secretariat of the parliament, in Chapter $\mathrm{V}$ Assistant to the Economy and Development on Article 21 established on December 20, 2019. In carrying out the duties referred to in paragraph (2), In carrying out the duties, functions and duties referred to in paragraph (2), paragraph (3) and paragraph (4), Assistant in charge of Part of the Economy. The Administration Development, the Procurement of Goods and Services; and Section Natural Resources. In Article 30 of the Regulations of the Mayor of Batam No. 56 of 2019 About the main Tasks, Functions and Duties of the Regional Secretariat and the Secretariat of the parliament, the Procurement of Goods and Services led by a Head of Section. In carrying out the duties, functions and duties referred to in paragraph (2), (3), and paragraph (4), the Head of Section in charge: Sub-Section Management of the Procurement of Goods and Services; Sub-Part Management, Electronic Procurement Service; and Sub-Section of the Guidance and Advocacy for the Procurement of Goods and Services. Article 31 of the Regulations of the Mayor of Batam No. 56 of 2019 About the main Tasks, Functions and Duties of the Regional Secretariat and the Secretariat of the parliament; Sub-Part of the Management of the Procurement of Goods and Services led by a Head of Section. Article 32 of the Regulation of the Mayor of Batam No. 56 of 2019 About the main Tasks, Functions and Duties of the Regional Secretariat and the Secretariat of the parliament; Sub-Part Management, Electronic Procurement Service led by a Head Sub-Section.

The steps in the implementation of programs and activities that begins with the Budget User after receiving the Documents the Implementation of the Budget of the Unit Depending on the Device Area immediately implement the appropriate activities are listed in the DPA-SKPD. Then the User of the Budget proposed to the Mayor of Batam name-the name of the authorized Budget for the activities to be delegated to the next set with the decision of the Mayor of Batam.

Furthermore, the Budget Users pointed Commitment Officer and Officials of the Procurement of Goods/Services will be determined by the Decision of the Head of SKPD as Budget Users. Budget users, Power Users to Budget and/or PPK once set to immediately carry out the activities in accordance with the duties and functions.

User Budget/the Budget Users who visit the department to other areas or to outside the country, the education and training/courses, hajj, hospitalized, on leave, or other reasons that are similar to it is absent in carrying out their duties at least 7 (seven) working days, then to ensure the smooth implementation of the task immediately appoint other officials in their environment as daily executor. Appointment as Executive is created with the Mail Command. Then PA/KPA draw up terms of Work Reference/ Work Plan activity as a preliminary step to the implementation of the activities.

The organization of the procurement of government goods/services procurement through the provider of the goods/services and procurement through self-management consists of:

\section{a. PA/KPA}

Article 1 of Presidential decree No. 16 of 2018 On Procurement of Goods/Services of the Government, which is also in line with the definition contained in Article 1 point 12 of the Law No. 1 of 2004 On State Finance. Based on article 6 paragraph (1) of Law Number 1 Year 2004 stated that the Head of SKPD can be a PA for SKPD.

\section{b. Commitment Officer}

In Article 1 paragraph 10 of Presidential decree No. 16 of 2018 defines the PPK is the official authorized by the PA/KPA to take a decision and/or action that may 
result in the expenditure budget of the state/area.

c. ULP/ Procurement Officials

In Article 1, the number 13 Presidential Regulation Number 16 Year 2018 defines the Procurement officer is the official administrative/functional officials/personnel in charge of carrying out the Procurement of Direct, Direct Appointment, and/or E-purchasing. ULP in carrying out their duties, assisted by a Working Group (WG) consisting of Civil Servants certified Expert Procurement of Goods/Services. Package procurement/construction work/services other which is worth the most high Rp. 200.000.000,00 (two hundred million rupiah) can be implemented by the PSU or one (1) Procurement Officials (PP). Package procurement of consulting services, which is worth the most high Rp. 50.000.000,00 (fifty million rupiah) can be implemented by the PSU or one (1) person of the Procurement officer and procurement conducted by one (1) PP.

d. Committee/Officials Of The Recipient Of The Results Of The Work

In Article 1 number 14 of Presidential Regulation Number 16 Year 2018 defines the Officials are Examining the Results of the Work is the official administrative/ functional officials/ personnel in charge of examining the administration of the results of the job Procurement of Goods/Services. In Article 1 number 15 of Presidential decree No. 16 of 2018 defines the audit Committee the Results of the Work is a team that is in charge of examining the administration of the results of the job Procurement of Goods/Services.

\section{The Mechanism of Procurement of Goods/Services}

The mechanism of procurement of goods/services in Batam City Spatial Planning and Creation Service has no rules and mechanisms for the procurement of goods/services of its own (special), but still follow the rules and the mechanism or SOP that has been specified in the Regulations of the Mayor of Batam.

Before the implementation of the procurement, analysis and evaluation of the needs, as well as procurement planning. The implementation of the procurement of goods/services through the provider is an activity to follow-up on procurement planning that has been carried out by the Users Budget (PA)/(KPA).

\section{a. Planning The Procurement Of Goods/Services}

Procurement planning is carried out simultaneously with the process of the preparation of the Work Plan and the Budget of the Region after the memorandum of understanding Budgets and Priorities and Plaforn Budget While (KUA-PPAS). In order to improve the quality of procurement planning conducted by the KDP, the process of the preparation of the procurement planning can be assisted by the Work Unit for the Procurement of Goods/Services, Goods/Services Procurement Manager, Agent, Team or Experts, Technical Team, Support Team and/or unit other work related to procurement planning.

b. Preparation Of Procurement of Goods/Services

For the preparation of the procurement of goods/services that a portion of the fee or wholly charged to the budget of the City of Batam, can be implemented after RKA Device Area approved by the city council of the City of Batam. For the procurement of goods/services for which the contract must be signed at the beginning of the year, preparation of procurement and/or the selection of a provider can be implemented after the approval of the RKA Device Area in accordance with the provisions of laws and regulations. PPK draft a contract that contains the type of contract, form of contract, the text of the treaty, down payment, certificate of warranty, certificate/documents in the framework 
Hamidi et.al. Juridical analysis on the procurement of goods/services of the government to realize good governance (Research studies in the department of human settlements and layout Batam City)

of the procurement of imported goods, the general terms of contract, as well as the special conditions of contract when necessary. The guarantee of the procurement of goods/services functions for the control and mitigation of the risk of possible failures or delays the process of the procurement of goods/services at the stage of execution of the contract. The guarantee of the procurement of goods/services can be in the form of a bank guarantee or surety bond. Warranty certificate in procurement of goods/services required to ensure the airworthiness of the use of the goods, which states that the existence of a guarantee of the availability of spare parts as well as the facilities and aftersales service. Procurement of goods imported must include requirements documents items, such as supporting letter/letter of intent/letter of agreement from the manufacturer/principal in the country of origin are listed in the document selection by uploaded by the businesses to the Application SPSE the time of submission of the bidding documents. Certificate of origin (certificate of origin) and production certificate submitted by the Provider to the KDP time of handover of work.the requirements of the certificate of origin and a certificate of the products included in the draft contract. In preparing the SSKK lists the number of clauses detailed in SSUK. Charging SSKK is carried out simultaneously with the preparation of the draft contract.

c. The Preparation Of The Selection Of The Provider

The preparation of the selection of providers by Procurement Officials through direct Procurement implemented after the Procurement Officials received a request document the selection of the provider of the PPK and then Procurement Officials download documents preparation of procurement that have been uploaded by the KDP through the SPSE.

\section{d. The Implementation Of The Selection Of The Provider}

e. The Execution Of The Contract

At this stage includes the Signing of the Contract, the Implementation of the Signing of the Contract, the Submission of the Job Site, Mail Orders Work Start/ writ of Delivery (SPP), the Provision of Advance, the Preparation of the Quality Program, a Meeting in Preparation for Execution of the Contract, Mobilisasipaling slow should already begin to be implemented according to the set time and the scope of work, a Joint Inspection, Control of the Contract, the Inspection of Fabrication, the Payment of the Achievements of the Work, Changes to the Contract, force majeure, Termination of the Contract or Expiration of the Contract, the Provision of Opportunity, Fines and compensation, The Handover, The Maintenance Period.

The theory of a Legal System that delivered by Lawrence $M$. Friedman, namely on the elements of the substance of the law (legal substain) and elements of cultural or culture (legal culture), then on the substance of the law will determine that whether or not a law can be implemented, then the substance of the law also means that a legal product that is produced by people who are in the legal system that includes the decisions they take out, the new rules that they set. The substance of the law also includes a law of life (living law), not just the rules that are in the Book of the Law (law books) and the law of life in the community can be used as a reference in building equitable law. The law, according to Austin is non optional. Austin argues that states the law is a kind of rule that has moral structures internal to itself must meet the requirements in the rules to become a law.

Presidential regulation Number 16 Year 2018 On Procurement of Government Goods/Services has a substance in the form of the legal regulation on procurement of goods/services in the government both at the central and local government, which is next in the City of Batam is formed again Rule 
the Mayor of Batam associated with the Implementation of Procurement of Goods/Services in the Batam City Government. As for the rules that made sure to realize the implementation of the procurement of goods/services that are simple, clear and comprehensive, in accordance with the good corporate governance, so it can be an effective setting for the parties related to the procurement of goods/services of the government.

The practice of procurement of goods/services needs to be improved, to refer to a technique (method) and the process has been standardized and widely accepted, both nationally and internationally. Improving the quality of the procurement of goods/services can be improved from the process or the execution of which has been traversed and evaluated for improvement in the future or it could also adopt best practices (best practices) that has been successfully carried out in other countries. Although each state has needs that are not all the same (different) with all its consequences, but of course can keep our adoption of the positive side of best practice such.

Some international organization such as the European Community (EC), the International Standardization Organization (ISO), a variety of analysis or the views of the academics that can be used as a material consideration in the development of the legal arrangements for the implementation of the procurement of goods/services desired and aspired to. On the organization of the EC, the application of best practices in the regulation of the procurement of goods/services in terms of the so-called "Directive 2014/24/EU Of The European Parliament and Of The Council of 26 February 2014 on public procurement and repealing Directive 2004/18/EC," which was signed by 28 countries members of the EC, namely Belgium, Bulgaria, Czech Republic, Denmark, Germany, Estonia, Ireland, Greece, Spain, France, Croatia, Italy, Cyprus, Latvia, Lithuania, Luxembourg, Hungary, Malta, the
Netherlands, Austria, Poland, Portugal, Romanian, Slovenian, Slovak, Finnish, Swedish, and the United kingdom.The provisions of the next mengitkat to be implemented in the national legal system of each member states. In article 18 to 21 of Directive governing principles of procurement, which states that the apparatus of the procurement should treat providers equally important and without discrimination, must act in a transparent and balanced, maintain the integrity of, find the best price for each procurement, and act efficiently in the use of public funds in procurement of goods/services.

On the Presidential Regulation Number 162018 at the Article 5 letter b expressed about the policy for the procurement of goods/services to carry out the procurement of goods/services that is transparent, open and competitive. Furthermore, article 6 of the letters $d$ and e states that the procurement of goods/services apply the principle of open and competitive. Article 22 paragraph (3) also requires the announcement of the Public Procurement Plan in Ministries/Agencies and Regional using the Information System of the Public Procurement Plan are web-based. Furthermore, article 22 paragraph (4) states that the announcement of the RUP Ministry/Agency/Local Devices can be added in the website of the Ministry/ Agency/Local Government, the board official announcement to the public, newspapers, and/or other media. Methods the tender announcement is applied to ensure the creation of the selection of the provider of goods/services that compete. Application Information System of the Public Procurement Plan aims to facilitate the entity procurement in announcing RUPhis, and as a means of public service to facilitate public access in the direct procurement of goods/services.

The wisdom of the government which can be seen from the background of the issuance of Presidential Regulation Number 16 Year 2018 is the country's 
commitment to enhance the role of micro and small businesses. Article 65 paragraph (3) and (4) regulating the packaging is done by assigning as much as possible package for small businesses, and the value of the procurement packages at most Rp.2.500.000.000,00 (two billion five hundred million) is reserved and intended for small businesses. Whereas in article 65 paragraph (6) states that the provider is undertaking a non-small carrying out the work can do business cooperation with small businesses in the form of partnership, subcontracting, or form of cooperation, if there are small businesses that have the ability in the field concerned. This provision will protect micro and small businesses from competition against the provider of the goods/services non-small. Although this condition is contrary to best practice (best practice) of the international world that does not restrict competition between small businesses and non-small.

\section{Factors That Become Obstacles and Obstacles in the Implementation of the Procurement of Goods/Services at the Department of Human Settlements and Spatial Planning of Batam City}

The number of cases of procurement of goods/services of the government that occurred in Indonesia, either civil cases or criminal cases of corruption, caused by several factors-the factors that cause the problems in the implementation of procurement of goods/services so that the impact is still the number of officials such as commitment officer, the working Group Selection/Procurement officer/PPTK do not realize that the consequences settings tender or direct appointment erroneous or not in accordance with the regulations related to the implementation of the procurement of goods/services. This can certainly cause against the law. Many commitment officer who do not read and understand well against the tender documents or the contract will be signed. Whereas the tender documents is the legal basis for the providers of goods/services and the user of the goods/services in the tender (the Book of the Law of Civil Law Article 1338). Some commitment officer does not understand the meaning and provisions outlined in the tender document/contract document, so that the result is a lot of give rise to a claimclaims that can not be avoided, which then had to be met in the implementation of the contract. Another issue is the impact of Law Enforcement Officers and Auditors who have the knowledge and understanding of a very limited system of procurement of goods/services of the government and its authority in solving the problems of procurement of goods/services, so often make mistakes in understanding and set the status of the case, including a civil case or a criminal.Some of the other issues in the contract for the procurement of goods/services of the government which is always the case is in connection with the extension of the time of execution of the work, termination of the contract unilaterally, the provider of goods/services that is entered into the black list, the price adjustment in the implementation of the contract, the payment of the achievements of the work, the circumstances of force majeure, the goods are discontinued, the presence of subcontracting and the problem of delay penalty.

At this time, there are still a few things that is still an obstacle in the implementation of procurement of goods/services of the government, as follows;

1. The determination of the Head of the Work Unit is the authority Head in accordance with applicable Local laws and regulations. The regional head office are usually not necessarily the same with the years of Regional Revenue and Expenditure Budget, give impact to the smooth implementation of government procurement.

2. The competence of the Human Resources (HR) in Dinas Cipta Karya dan Tata Ruang Kota Batam. The number of Civil Servants (civil servants) who have the skills certification 
Hamidi et.al. Juridical analysis on the procurement of goods/services of the government to realize good governance (Research studies in the department of human settlements and layout Batam City)

procurement of government goods/services in Batam City Spatial Planning and Creation Service is still very minimal. Each of the officials assigned as Commitment Officer must have a certification of expertise in the procurement of goods/jasasesuai with the new provisions are based on the Presidential Regulation Number 16 Year 2018 On Procurement of Goods/Services of the Government. The committee of receiving the Results of the Work that has the certification of procurement of goods/services is still very low. Each of the officials assigned as Commitment Officer must have a certification of expertise in the procurement of goods/services that are still valid (not expired) so in accordance with the regulations, there are even staff that have never been completely follow the training and/or technical guidance to the procurement of goods/services of the government, so it has the ability and limited knowledge on the procurement of goods/services of the government.

3. The availability of the Expert Contract Law/ Contract Construction is very difficult to obtain the services in meeting the requirements of Presidential decree No. 16 of 2018 established that the contract for complex or worth over Usd.100.000.000.000 (one hundred billion rupiah), before signature of the contract, then it must have got the approval of the Experts in the Law of Contract / Construction.

4. Other issues in the contract for the procurement of goods/services of the government which is always the case is in connection with the extension of the time of execution of the work in excess of the budget year. The absence of adequate regulatory and instructions of engineering against the force majeure in the procurement of government goods/services. As it is known that the current outbreak (pandemic) Virus Covid-19, which makes a postponement of the implementation of the procurement of government goods/services.

\section{Efforts to Resolve the Constraints and Obstacles in the Implementation of Government Goods/Services Procurement}

In the Annex to the Regulation on the Mayor of Batam Number 49 Years 2019 On Guidelines for the Direct Procurement of Electronic, explaining that in the event of a change in the Official Maker of the Commitment on the implementation of the planning, then do the handover to the Commitment Officer, the new and the task of planning the procurement of the switch becomes the task of the Commitment Officer new. Appointment as Executive is created with the Mail Command. Then PA/KPA draw up terms of Work Reference/Work Plan activities as a first step.

Increase the competence of Human Resources (HR) Department of human settlements and spatial planning of the City of Batam in the field of procurement of goods/services of the government continued. Department of Human Settlements and Batam City Spatial Planning budgets it every year.

Civil servants (civil servants) who do not yet have the certification of procurement of goods/services of the government in the Department of Human Settlements and Batam City Spatial Planning necessarily have to follow the program of increase in competence, so that the process of implementation of the procurement of government goods/services can be performed optimally and professional as expected related regulations. In addition to the presence of discernment and clarity to the job description of each employee, either civil servants or employees are not fixed (honorary).

Giving the opportunity to the provider to complete the work outlined in an addendum to the contract that governs the imposition of the sanctions delay to the provider and the extension of the period of 
Hamidi et.al. Juridical analysis on the procurement of goods/services of the government to realize good governance (Research studies in the department of human settlements and layout Batam City)

validity of performance security (if any). Giving the opportunity to the provider complete the work up to 50 (fifty) calendar days, since the end of the execution of the work. Guidelines for procurement in handling the procurement of emergency has been regulated in the LKPP No. 13 of 2018 on Procurement of Goods/Services in a State of Emergency and the Circular Letter of LKPP Nomor 3 Tahun 2020 tentang Explanation of the Implementation of the Procurement of Goods/Services in Order to Handling of the Corona Virus Disease 2019 (Covid-19), as well as for the procurement in a state of emergency is set by Presidential Regulation Number 162018 in Chapter VIII Special Procurement. In a Circular Letter With the Number 119/5059/SJ About the Follow-on Contract for the Procurement of Goods/Services To the Adjustment of Regional Revenue and Expenditure Budget 2020 as the Impact of the State of Emergency Public Health as a National Disaster Corona Virus Disease-2019 (Covid-19), which is the follow-up of the Government Regulation in Lieu of Law No. 1 of 2020 On the Financial Policy of the Country and the Stability of the Financial System For Penganana Pandemic Corona Virus Disease 2019 (Covid-19) and/or In Order to Face the Threat that Harm the Economy of the National and/or Stability of the Financial System and the Presidential Decree No. 12 of the year 2020 On the Determination of Disasters Non Natural Spread of the Corona Virus Disease 2019 (Covid-19) as a national disaster. For jobs that enter the program who entered the program a priority according to the budget in 2020, especially to ensure the continuity of the fulfillment of the basic public services that can't be postponed its completion, the contract continues until the entire job is completed and payment is charged in the budget year 2020 or 2021. The main principle put forward is the effectiveness while maintaining accountability.

\section{CONCLUSIONS AND RECOMMENDATIONS Conclusion}

Based on the results of research that have been described in the discussion in the previous chapters, the authors conclude as follows:

1. The legal regulation based on the hierarchy of laws and regulations in Indonesia, as regulated in Law Number 12 Year 2011 On the Establishment of Laws and Regulations and Article 1 paragraph (3) of the constitution of the Republic of Indonesia Year 1945, which stated that Indonesia is a Country of Law. The implementation of the procurement of goods/services stipulated in Presidential Regulation Number 16 Year 2018 On Procurement of Goods/Services of the Government.

2. The implementation of the procurement of goods/services in Batam City Spatial Planning and Creation Service has been implemented based on the Presidential Regulation Number 16 Year 2018 On Procurement of Goods/Services of the Government and some other technical rules. In practice, there are still a few things that should be fixed and optimized as required by the laws and regulations that apply.

3. The regional head office are not the same as the year of Regional Revenue and Expenditure Budget giving effect to the smooth implementation of government goods/services procurement. The vacancy at the head of the department which is then filled by the Executor of the task will give the impact is less effective in the procurement of goods/services. The competence of the Human Resources (HR) in Batam City Spatial Planning and Creation Service still need to improve knowledge and competence, in order to meet the qualifications of competence required by Presidential Regulation Number 16 Year 2018 On Procurement of Goods/Services of the Government and other relevant 
Hamidi et.al. Juridical analysis on the procurement of goods/services of the government to realize good governance (Research studies in the department of human settlements and layout Batam City)

regulations. Expert Contract Law/ Contract Construction is very difficult to obtain the services meet the requirements set forth, especially for complex jobs. The implementation of the work in excess of the fiscal year, which is no longer compatible with the initial agreement of contract for the procurement of goods/services of the government, which one of them caused by the outbreak of the disease Corona Virus Disease-2019 (Covid-19).

\section{Recommendations}

1. The implementation of this Presidential Regulation will be implemented optimally when supported by the regulations of the regional/ Mayor regulation on procurement of goods/ services of the local government, so that the settings of the law on the procurement of goods/services of the local government to be more comprehensive and can be used as guidelines in the procurement of goods/services of the government of the City of Batam.

2. The need for increased knowledge and understanding of procurement of government goods/services through the socialization and training of procurement of goods/services of the government for the employees in the Batam City Spatial Planning and Creation Service. Increased knowledge and understanding of these will encourage the good level of compliance employees in implementing or applying the relevant regulations.

3. The competence of human resources the Batam City Spatial Planning and Creation Service, which should be increased to meet the qualification of competence required by Presidential Regulation Number 16 Year 2018 On Procurement of Goods/Services of the Government and other relevant regulations. KDP can provide opportunity provider for complete the job procurement of goods/services of the government with reference to Circular Letter With the Number 119/5059/SJ About the Follow-up Contract for the Procurement of Goods/Services To the Adjustment of Regional Revenue and Expenditure Budget 2020 as the Impact of the State of Emergency Public Health as a National Disaster Covid-19.

\section{Acknowledgement: None}

\section{Conflict of Interest: None}

\section{Source of Funding: None}

\section{REFERENCES}

1. Ariman Sitompul, Maswandi, 2021, Nikah Poliandri Dalam Perpektif Pidana Islam dan Hukum Positif di Indonesia, Malang:Mazda Media.

2. Ariman Sitompul, Pagar, Mhd.Syahnan, The Criminal Replacement Of Fine In Law Of Money Laundering Number 8 Of 2010 (Case Study in Nort Sumatera), International Journal Of Creative Research Thoughts, Vol.8, No.11,2020.

3. Fakih, Mansour, 2001, Sesat Pikir Teori Pembangunan dan Globalisasi, Penerbit Pustaka Pelajar, Yogyakarta.

4. Friedrich, Carl Joachim, 2004, Filsafat Hukum Perspektif Historis. Nuansa dan Nusamedia, Bandung.

5. Hamzah, Andi, 2001, Asas-Asas Hukum Pidana, Rineka Cipta, Jakarta.

6. http://eproc.lkpp.go.id/goto/tentangeprocurement, diakses pada 26 Maret 2020.

7. http://eproc.lkpp.go.id/goto/tentangeprocurement, diakses pada 26 April 2020.

8. https://www.kpk.go.id/id/statistik/penindaka n/tpk-berdasarkan-jenis-perkara, diakses pada 26 Maret 2020.

9. Hutchinson, Terry, 2002, Researching and Writing in Law,Law book Co, Sidney.

10. Idham, 2004, Konsolidasi Tanah Perkotaan dalam Perspektif Otonomi Daerah, Penerbit Alumni, Bandung.

11. Keputusan Walikota Batam Nomor: KPTS. 319/HK/XII/2018 Tentang Standar Operasional Prosedur Bagian Pengadaan Barang dan Jasa Sekretariat Daerah Kota Batam.

12. Kusumaatmadja, Mochtar, 2002, Konsepkonsep Hukum dalam Pembangunan, Penerbit Alumni Bandung. 
Hamidi et.al. Juridical analysis on the procurement of goods/services of the government to realize good governance (Research studies in the department of human settlements and layout Batam City)

13. Lampiran I Peraturan Walikota Batam Nomor 49 Tahun 2019 Tentang Pedoman Pengadaan Langsung Secara Elektronik.

14. Lawrence M. Friedman, 2001, Hukum Amerika: Sebuah Pengantar (American Law: An Introduction), Penerjemah oleh Wishnu Basuki, Jakarta: PT. Tatanusa.

15. Lawrence M. Friedman, 2009, Sistem Hukum: Perspektif Ilmu Sosial (The Legal System: A Social Science Perspective), Penerbit Nusa Media, Ujung Berung, Bandung.

16. Lili Rasjidi dan I.B., Wyasa Putera, 2003. Hukum Sebagai Suatu Sistem, Bandung: Mandar Maju.

17. Maswandi, Ariman Sitompul, 2020, Tindak Pidana Korupsi Dibalik Kontrak Pengadaan Barang/Jasa, Yogjakarta: K-Media.

18. Maswandi, Ariman Sitompul, 2020, Perampasan Aset Hasil Tindak Pidana Pencucian Uang Dengan Asal Pidana Korupsi, Malang: Mazda Media.

19. Mhd.Nasir Sitompul, Ariman Sitompul, The Combination Of Money Laundering Crime With The Origin Of Narkotics Crime To Islamic Law, Proceeding International Seminar of Islamic Studies, Vol.1. No.1, 2020.

20. Muh. Ali Amran, 2010, Sistem Hukum Indonesia, diakses dari http://justitia1.wordpress.com/sistemhukum-indonesia/. diakses pada 20 April 2020.

21. Nadapdap, Binoto, 2009, Hukum Acara Persaingan Usaha, Jala Permata Aksara, Jakarta.

22. Peraturan Lembaga Kebijakan Pengadaan Barang/Jasa Pemerintah Nomor 9 Tahun 2018 Tentang Pedoman Pelaksanaan Pengadaan Barang/Jasa Melalui Penyedia.

23. Peraturan Menteri Pendayagunaan Aparatur Negara dan Reformasi Birokrasi Nomor 77 Tahun 2012.

24. Peraturan Pemerintah Nomor 12 Tahun 2019 Tentang Pengelolaan Keuangan Negara (Lembaran Negara Republik Indonesia Tahun 2019 Nomor 42, Tambahan Lembaran Negara Republik Indonesia Tahun 2019 Nomor 6322).

25. Peraturan Presiden Nomor 16 Tahun 2018 Tentang Pengadaan Barang/Jasa Pemerintah (Lembaran Negara Republik Indonesia Tahun 33).

26. Peraturan Presiden Republik Indonesia Nomor 54 Tahun 2010 Tentang Pengadaan
Barang/Jasa Pemerintah. (Lembaran Negara Republik Indonesia Tahun 2014 Nomor 368, Tambahan Lembaran Negara Republik Indonesia Nomor 5642).

27. Peraturan Walikota Batam Nomor 56 Tahun 2019 Tentang Tugas Pokok, Fungsi dan Uraian Tugas Sekretariat Daerah dan Sekretariat DPRD, pada Bab V Asisten Perekonomian dan Pembangunan.

28. Philippe Nonet dan Philip Selznick, 1978. Hukum Responsif Pilihan di Masa Transisi, Penerjemah Rafael Edy Bosco, Jakarta: HuMa.

29. Rato, Dominikus, 2010, Filasafat Hukum Mencari dan Memahami Hukum, PT Presindo, Yogyakarta.

30. Simamora, Sogar, 2013, Hukum Kontrak: Kontrak Pengadaan Barang dan Jasa Pemerintah di Indonesia. Wins \& Partners Law Firm dan Lbj. Surabaya.

31. Surat Edaran Bersama Nomor 119/5059/SJ Tentang Tindaklanjut atas Kontrak Pengadaan Barang/Jasa Terhadap Penyesuaian Anggaran Pendapatan dan Belanja Daerah Tahun 2020 sebagai Dampak Keadaan Kedaruratan Kesehatan Masyarakat sebagai Bencana Nasional Corona Virus Disease-2019 (COVID-19).

32. Surat Kepala Badan Kepegawaian Negara Nomor K.26-20/V.20-25/99.

33. Undang-Undang Dasar Negara Republik Indonesia Tahun 1945.

34. Undang-Undang Nomor 1 Tahun 2004 Tentang Perbendaharaan Negara (Lembaran Negara Republik Indonesia Tahun 2004 Nomor 5, Tambahan Lembaran Negara Republik Indonesia Nomor 4355).

35. Undang-Undang Nomor 17 Tahun 2003 tentang Keuangan Negara (Lembaran Negara Republik Indonesia Tahun 2003 Nomor 47, Tambahan Lembaran Negara Republik Indonesia Nomor 4286).

36. Undang-Undang Nomor 2 Tahun 2017 Tentang Jasa Konstruksi (Lembaran Negara Republik Indonesia Tahun 2017 Nomor 11, Tambahan Lembaran Negara Republik Indonesia Nomor 6018).

37. Undang-Undang Nomor 20 Tahun 2001 Tentang Pemberantasan Tindak Pidana Korupsi (Lembaran Negara Republik Indonesia Tahun 2001 Nomor 134, Tambahan Lembaran Negara Republik Indonesia Nomor 4150).

38. Undang-Undang Nomor 5 Tahun 1986 Tentang Peradilan Tata Usaha Negara 
Hamidi et.al. Juridical analysis on the procurement of goods/services of the government to realize good governance (Research studies in the department of human settlements and layout Batam City)

(Lembaran Negara Tahun 1986 Nomor 77; Tambahan Lembaran Negara Nomor 3344).

39. Undang-Undang Nomor 9 Tahun 2015 Tentang Pemerintah Daerah (Lembaran Negara Republik Indonesia Tahun 2015 Nomor 58, Tambahan Lembaran Negara Republik Indonesia Nomor 5679).

40. Undang-Undang Republik Indonesia Nomor 30 Tahun 2014 Tentang Administrasi Pemerintahan (Lembaran Negara Tahun 2014 Nomor 292).
How to cite this article: Hamidi, Gayo S, Sitompul A. Juridical analysis on the procurement of goods/services of the government to realize good governance (Research studies in the department of human settlements and layout Batam City). International Journal of Research and Review. 2021; 8(11): 63-77. DOI: https://doi.org/10. 52403/ijrr.20211109 